\title{
Petroleum Hydrocarbon Residues in Surficial Sediment Samples from Aden City Coasts, Yemen
}

\author{
Ibrahim A. Al-Akhaly ${ }^{1 \star}$, Nabil A. Al-Shwafi ${ }^{1}$, Basem Y. Al-Matari ${ }^{2}$ and Eman I. Siam ${ }^{3}$
}

${ }^{1}$ Department of Earth and Environmental Science, Faculty of Science, Sana'a University, Yemen; ${ }^{2}$ Maritime Affairs Authority, Aden Branch, Yemen; ${ }^{3}$ Arab Academy for Science, Technology and Maritime Transport, Alexandria,Egypt. Email:Ibnalakhaly@hotmail.com.

\begin{abstract}
The environmental quality along Aden coasts is affected by the anthropogenic pressure of Aden city. Field work has been carried out to investigate the occurrence of petroleum pollution along these coasts. To determine the status of aliphatic hydrocarbon $(\mathrm{AH})\left(n-\mathrm{C}_{10}\right.$ to $\left.n-\mathrm{C}_{34}\right)$ and polycyclic aromatic hydrocarbon $(\mathrm{PAH})$ pollution in surface sediments, twenty seven surface sediment samples were collected in July and December 2014 and March 2015 and analysed for AHs and PAHs by using gas chromatography-mass spectrometry (GC-MS) to determine their levels and sources. Concentrations of AHs ranged from $6.25 \mu \mathrm{g} / \mathrm{g}$ at station 5 (Goldmoor) to $41.05 \mu \mathrm{g} / \mathrm{g}$ at station 7 (Al Ghadir coast) with an average of $16.49 \mu \mathrm{g} / \mathrm{g}$. Concentrations of PAHs were in the range between $0.37 \mu \mathrm{g} / \mathrm{g}$ at station 5 (Goldmoor) and $16.30 \mu \mathrm{g} / \mathrm{g}$ at station 9 (Oil Harbor) with an average of $7.38 \mu \mathrm{g} / \mathrm{g}$. The study showed that the levels of petroleum hydrocarbons ( $\mathrm{PHs}$ ) in coastal sediments are low and within the allowed limits. The major sources of the pollution were petrogenic in origin, based on the indices of AHs and PAHs. This pollution is a result of localized oil operations and/or heavy ship traffic in the Gulf of Aden. The results will be used to assess the ecosystem quality. Environmental control is recommended to reduce the marine pollution of Aden coasts.
\end{abstract}

Keywords: Aden; Coastal sediments; Gulf of Aden; Petroleum pollution; Yemen

$$
\text { بقايا الهيدروكريونات التفطية في عينات رواسب سطحية مأخوذة من سواحل مدينة عدن، اليمن }
$$

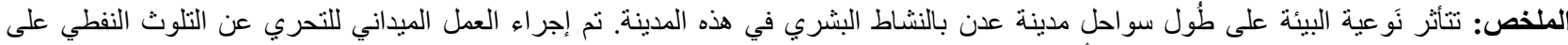

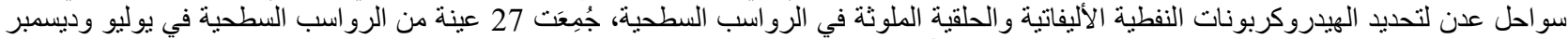

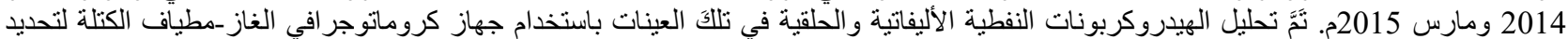

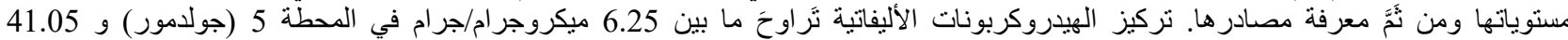

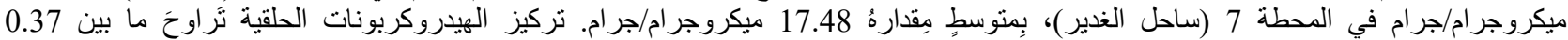

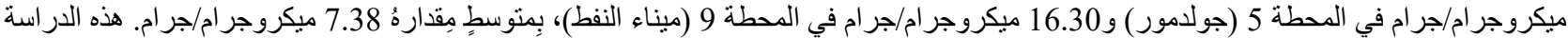

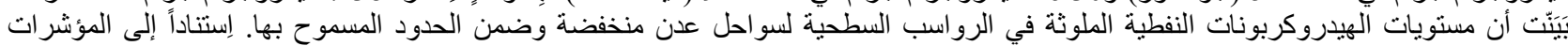

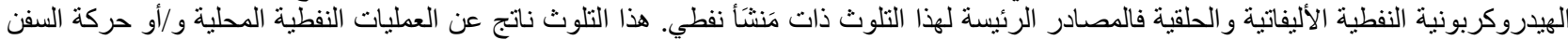

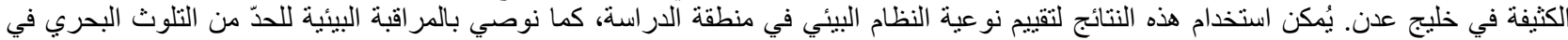
سو احل عدن. الكلمات المفتاحية: عدن، الرواسب الساحلية، خليج عدن، التلوث البحري، اليمن.

\section{Introduction}

oastal environments are considered to be places of high ecological risk due to complex biogeochemical processes and intensive human activities [1]. Recently, due to rapid economic development, industrialization and urbanization, persistent organic pollutants such as AHs and PAHs, have become highly concentrated in or near coastal areas [2]. 
Hydrocarbons are naturally occurring compounds which are important components of the sedimentary organic matter from coastal areas. Their composition and distribution are significantly affected by human activities. Petroleum hydrocarbons (PHs) come from biogenic, petrogenic, and/or pyrogenic sources [3,4], and have received much attention due to their wide distribution in marine sediments [5]. PHs enter the marine environment from many sources including industrial discharges, accidental spills, shipping activities, atmospheric fallout, and oil and gas exploration [6].

AHs and PAHs are the major components of crude oil, which is one of the main pollutants in coastal environments. AHs are the most abundant components of organic material found in marine sediments [7,8]. A high concentration of AHs is a potential source of pollution and may cause adverse effects on ecosystems [9]. PAHs are a wide group of compounds with two or more aromatic rings containing solely hydrogen and carbon [10]. AHs and PAHs are environmental pollutants produced by pyrogenic, natural processes and/or anthropogenic activities [11,12]. PAHs are also derived from crude oil and its derivatives [11,13].

The pollution of the marine environment by organic and inorganic pollutants in the Gulf of Aden and Arabian Sea is a major concern for all the countries in the region. The coastal waters of Yemen are characterized by their high productivity making them a basic feeding and nursery ground for marine species [14]. More than 600 species of marine organisms have been recorded in Yemeni waters [15]. However, the extent of pollution of the marine environment in the Yemeni coastal area by persistent organic pollutants is largely unknown. Untreated domestic wastewater, industrial wastewater, agricultural drain water, run-off during rainy periods, ship and boat traffic, oil transportation, oil spillage, and atmospheric fallout are all potential sources of pollution [16].

The Gulf of Aden is among the busiest tanker routes. Most of the oil produced in the region is exported via sea and pipelines, while refineries producing for local consumption are located in the coastal area. The widespread oil pollution in the Gulf of Aden is therefore not surprising [17-20], so a chronic input of hydrocarbons into the sediments is to be expected. On the other hand, the Gulf of Aden is characterized by a high water temperature $\left(>25^{\circ} \mathrm{C}\right)$ and a surface water salinity varying between 33.70 to $37 \%$ [21], which provide favorable conditions for oil degradation [22].

The aims of this study are: (1) to evaluate the concentrations of AHs and PAHs, and (2) to identify the sources of these pollutants in surface sediments collected along Aden coasts, Yemen.

\section{Study area}

Aden city is located on the coast of the Gulf of Aden in the south of Yemen. It is bounded by latitudes $12.70^{\circ}$ $12.90^{\circ} \mathrm{N}$ and longitudes $44.78^{\circ}-45.08^{\circ} \mathrm{E}$ (Figure 1). It is the economic capital of Yemen and the second most important Yemeni city after Sana'a. Aden is the largest coastal city and famous for transit trade, boat building, ship repairs and bunkering. Before the closure of the Suez Canal in 1967, Aden was the third largest bunkering port in the world. Besides port related activities, major economic resources in the coastal zone are fisheries, maritime traffic, and oil and gas exploitation. Crude oil is transferred by pipeline from the port to tankers. A large boat is available for transport of ship based garbage and oily waste, which is subsequently carried by lorries to a municipal landfill where it is burned. The port and entrance channel are dredged regularly and dredge spoil is dumped offshore [23].

\section{Materials and Methods}

Twenty seven surface sediment samples were collected to cover the coastal area of Aden, which is an area of intense industrial and urban activities. These samples were taken during July and December 2014, and March 2015 from nine selected stations (Figure 1). The samples were collected using a stainless steel Ekman's grab and kept frozen on dry ice until the time of analysis. Just before analysis, the sediment samples were thawed, dried in an oven at $40{ }^{\circ} \mathrm{C}$ overnight and ground by an agate motor. Because of the non-homogenous nature of these sediments, they were sieved through a $63 \mu$ sieve (silt and clay fraction). A reference sediment sample was collected from station 5 at Goldmoor area which is far from any expected oil pollution and is a protected natural area (Figure 1).

The Global Positioning System (GPS) was used to determine the coordinates of the sampling points. For the analysis of AHs and PAHs, $10 \mathrm{~g}$ of freeze-dried sediment was extracted with dichloromethane using an accelerated solvent extractor. The surrogates d8-Naphthalene, d10-Acenaphthene, d10-Phenanthrene, d12-Chrysene and d12Perylene were added to the samples prior to extraction. Concentrated extracts were fractionated with alumina/silica gel (80-100 mesh) column chromatography. Target analyses were eluted from the column with 50 ml of pentane (aliphatic fraction) and $200 \mathrm{ml}$ of $1: 1$ pentane-dichloromethane (PAH/PCB/pesticide fraction). These fractions were then concentrated to $1 \mathrm{ml}$ using Kuderna-Danish concentrator tubes, then the concentrated tubes heated in a water bath to between $60{ }^{\circ} \mathrm{C}$ to $70{ }^{\circ} \mathrm{C}[24,25]$. In this way the $\mathrm{AH}$ and $\mathrm{PAH}$ fractions were derived. The final determination was performed using GC-MS (a Shimadzu GC- 2010 C.N. 1134102760 Sa, with a split/splitless injector furnished with a $60 \mathrm{~m} \times 250 \mathrm{~mm} \times 25 \mu \mathrm{m}$ fused silica capillary with a chemically bonded gum phase DB-wax). Blank determinations were carried out by repeating the procedure with pre-extracted samples using a calibration with Marib export blend crude oil, the detector response was $45.8 \mathrm{mV}$ at $360 \mathrm{~nm}$ emission wavelength. The concentrations of the AH and PAH were calculated three times (for July and December 2014 and March 2015) and the mean values were taken. 


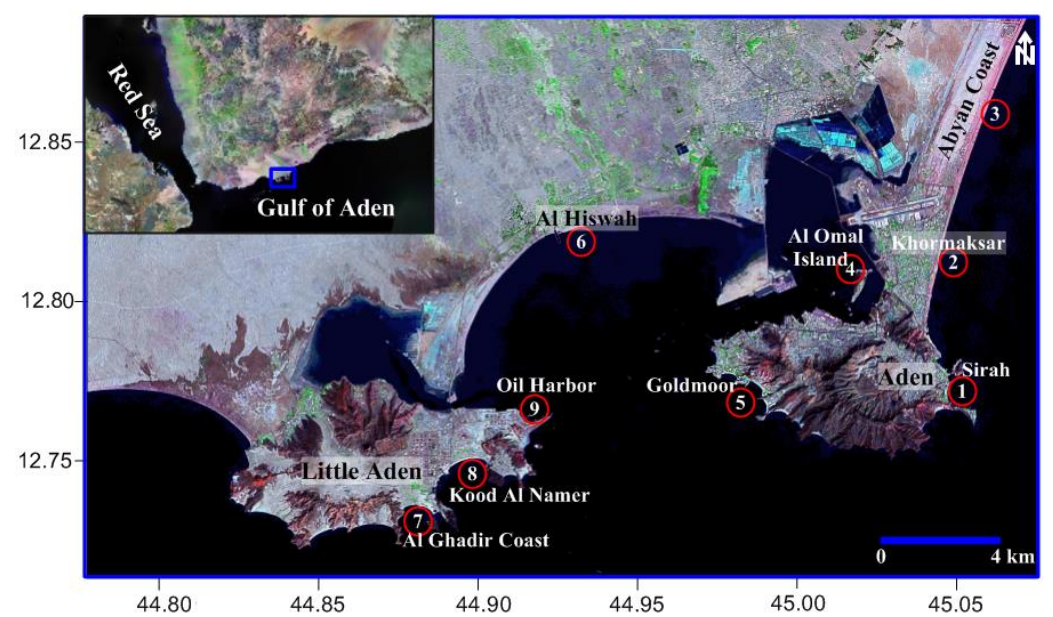

Figure 1. Location map of the study area and selected sampling sites.

To ensure an appropriate quality of analyses, matrix spikes, laboratory sample duplicates and laboratory blanks were processed with each batch of samples (10 samples/batch) as part of the laboratory internal quality control. Standards and blanks were analyzed under the same conditions as the samples. The quality control procedures satisfied their acceptable ranges. The recoveries were between 78-103\% and 87-105\% for AHs and PAHs, respectively. Reproducibility of analyses was tested by triplicate analyses of sediment extracts; it ranged from $3 \%$ to $10 \%$ of relative standard deviation. Standard Reference Materials (SRMs), provided by the National Institute of Standards and Technology (NIST) were analysed to monitor the performance of the analytical methods. The detection limit of AHs and PAHs was $0.01 \mu \mathrm{g} / \mathrm{g}$. Concentrations value in the sample analysed are reported as micrograms/gram $(\mu \mathrm{g} / \mathrm{g}) \mathrm{based}$ on dry sediment weight. Grain size analysis of the sediment was carried out using the combined dry sieve and pipette method [26]. Percentage Total Organic Carbon (\%TOC) was determined following the procedure of Riley and Chester [27], using the exothermic heating and oxidation of $1 \mathrm{~g}$ of milled dry sample with chromic acid. Samples were extracted and analysed at the Yemen Standardization, Metrology and Quality Control Organization, Sana'a, Yemen.

\section{Results and Discussion}

The results of pristane $(\mathrm{Pr})$, phytane $(\mathrm{Ph})$, squalane $(\mathrm{Sq})$ and $\sum \mathrm{AHs}$ concentrations in surface sediment samples from Aden city coasts are presented in Table 1. Concentrations of Pr range from $0.01 \mu \mathrm{g} / \mathrm{g}$ (station 4) to $0.05 \mu \mathrm{g} / \mathrm{g}$ (station 9), with an average of $0.03 \pm 0.02 \mu \mathrm{g} / \mathrm{g}$ (Table 1, Figure 2). The presence of Pr in significant concentrations supports the biogenic origin of hydrocarbons in surface sediment samples [28]. Concentrations of $\mathrm{Ph}$ range from 0.01 $\mu \mathrm{g} / \mathrm{g}$ (station 4) to $0.04 \mu \mathrm{g} / \mathrm{g}$ (station 3), with an average of $0.03 \pm 0.01 \mu \mathrm{g} / \mathrm{g}$ (Table 1, Figure 2).

Table 1. $\mathrm{Pr}, \mathrm{Ph}, \mathrm{Sq}, \mathrm{Pr} / \mathrm{Ph}, \mathrm{UCM}, \mathrm{CPI}$ and $\sum \mathrm{AHs}$ concentrations in surface sediment samples from selected Aden city coastal locations $(\mu \mathrm{g} / \mathrm{g})$.

\begin{tabular}{c|c|c|c|c|c|c|c}
\hline Station No. & $\mathbf{P r}$ & $\mathbf{P h}$ & $\mathbf{S q}$ & $\mathbf{P r} / \mathbf{P h}$ & $\mathbf{U C M}$ & $\mathbf{C P I}$ & $\sum$ AHs \\
\hline $\mathbf{1}$ & 0.01 & 0.03 & 0.04 & 0.56 & 0.70 & 1.20 & 09.77 \\
\hline $\mathbf{2}$ & 0.03 & 0.03 & 0.05 & 1.00 & 1.70 & 1.30 & 13.18 \\
\hline $\mathbf{3}$ & 0.04 & 0.04 & 0.04 & 0.81 & 1.50 & 1.10 & 12.02 \\
\hline $\mathbf{4}$ & 0.01 & 0.01 & 0.06 & 0.50 & 0.90 & 1.40 & 13.52 \\
\hline $\mathbf{5}$ & 0.01 & 0.02 & ND & 0.67 & 0.40 & 0.60 & 06.25 \\
\hline $\mathbf{6}$ & 0.04 & 0.03 & 0.08 & 1.56 & 1.70 & 1.50 & 10.31 \\
\hline $\mathbf{7}$ & 0.04 & 0.02 & 0.07 & 1.40 & 1.90 & 1.70 & 41.05 \\
\hline $\mathbf{8}$ & 0.04 & 0.03 & 1.00 & 1.40 & 2.00 & 1.70 & 31.50 \\
\hline $\mathbf{9}$ & 0.05 & 0.03 & 1.10 & 1.36 & 2.10 & 1.90 & 10.79 \\
\hline Average & 0.03 & 0.03 & 0.31 & 1.03 & 1.43 & 1.38 & 16.49 \\
\hline STDEV & 0.02 & 0.01 & 0.46 & 0.41 & 0.61 & 0.39 & 11.67 \\
\hline
\end{tabular}

$\mathrm{ND}=$ below detection of $0.001 \mu \mathrm{g} / \mathrm{g}$ 


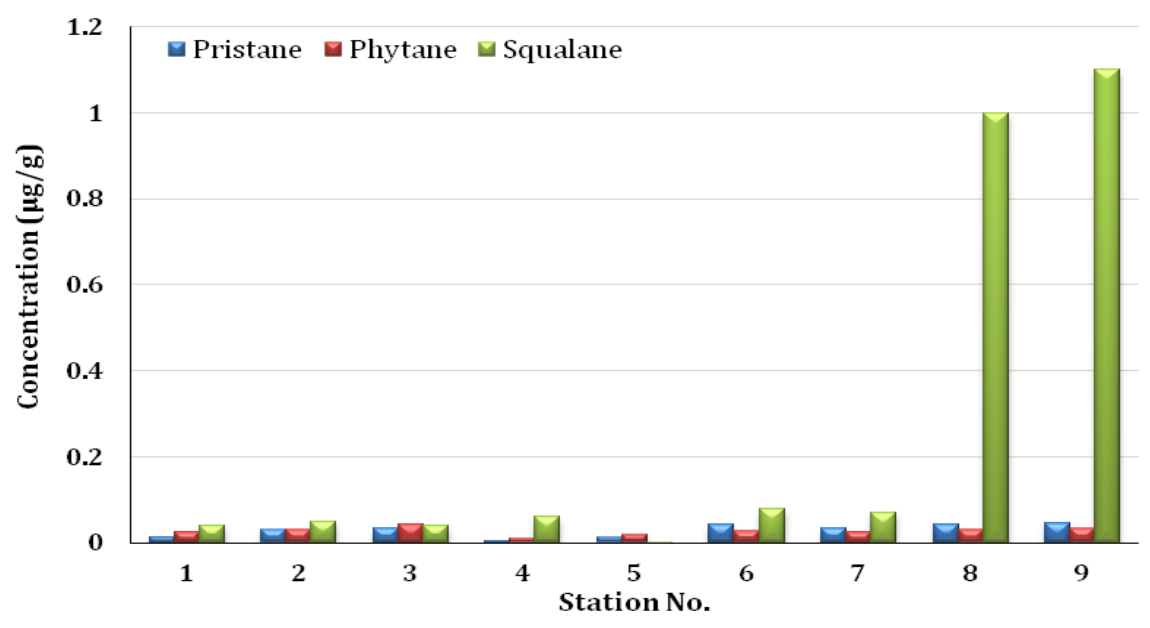

Figure 2. Concentrations of pristane, phytane, and squalane in surface sediment samples from nine stations along the Aden city coast.

The isoprenoids $\mathrm{Pr}$ and $\mathrm{Ph}$ are common components of crude oil. Ph originates from petroleum hydrocarbons, but Pr can be generated by biogenic processes in the absence of pollution by $\mathrm{PHs}[5,29]$. The ratio between $\mathrm{Pr} / \mathrm{Ph}$ is used to determine the relative contribution of oil to sediment pollution, where values close to or $<1$ indicate oil pollution, and values between 3 and 5 are characteristic of non-polluted sediments [3,29]. In this study, $\mathrm{Pr} / \mathrm{Ph}$ ratios varied between 0.50 and 1.56, indicating petroleum pollution (Table 1). Similar results were reported at oil polluted locations such as the Sfax in Tunisia [30] and Ushuaia Bay in Argentina [31].

Concentrations of Sq ranged from non-detected (ND) (station 5) to $1.10 \mu \mathrm{g} / \mathrm{g}$ (station 9), with an average of $0.31 \pm 0.46 \mu \mathrm{g} / \mathrm{g}$ (Table 1, Figure 2). Sq, which is a major organic constituent in polluted surface sediment, was intimately correlated with anthropogenic sources of hydrocarbons [32]. This compound was encountered in all the Aden coast sediment samples. This may help to indicate the nature of the pollution of these coasts. Burns et al. [28] reported that high concentrations of $\mathrm{Sq}$ in sediment samples indicate areas constantly subjected to chronic oil pollution.

The concentrations of unresolved complex mixture (UCM) ranged from $0.40 \mu \mathrm{g} / \mathrm{g}$ (station 5) to $2.10 \mu \mathrm{g} / \mathrm{g}$ (station 9), with an average of $1.43 \pm 0.61 \mu \mathrm{g} / \mathrm{g}$ (Table 1). The UCM represents components resistant to weathering and bacterial breakdown and its presence in chromatograms has frequently been taken as strong evidence for petroleum pollution in sediment samples [33]. The anthropogenic contribution of PHs is evident from the presence of the UCM in all of the samples analysed (Table 1).

The ratio of odd to even carbon numbered n-alkanes is called the carbon preference index (CPI). The CPI for the sediment samples ranged from $0.60 \mu \mathrm{g} / \mathrm{g}$ (station 5) to $1.90 \mu \mathrm{g} / \mathrm{g}$ (station 9), with an average of $1.38 \pm 0.39 \mu \mathrm{g} / \mathrm{g}$ (Table 1). It is the most common index for determination of the sources of AHs. CPI values $<3$ indicate petrogenic hydrocarbon inputs to the sediments, while natural inputs have values $>3$ [31,34-39]. The results of CPI of Aden coastal sediment reflect that all samples are polluted with petrogenic hydrocarbons (CPI < 1.90).

The linear regressions between UCM and CPI parameters show good significant correlation $\left(\mathrm{R}^{2}=0.69\right)($ Figure 3$)$.

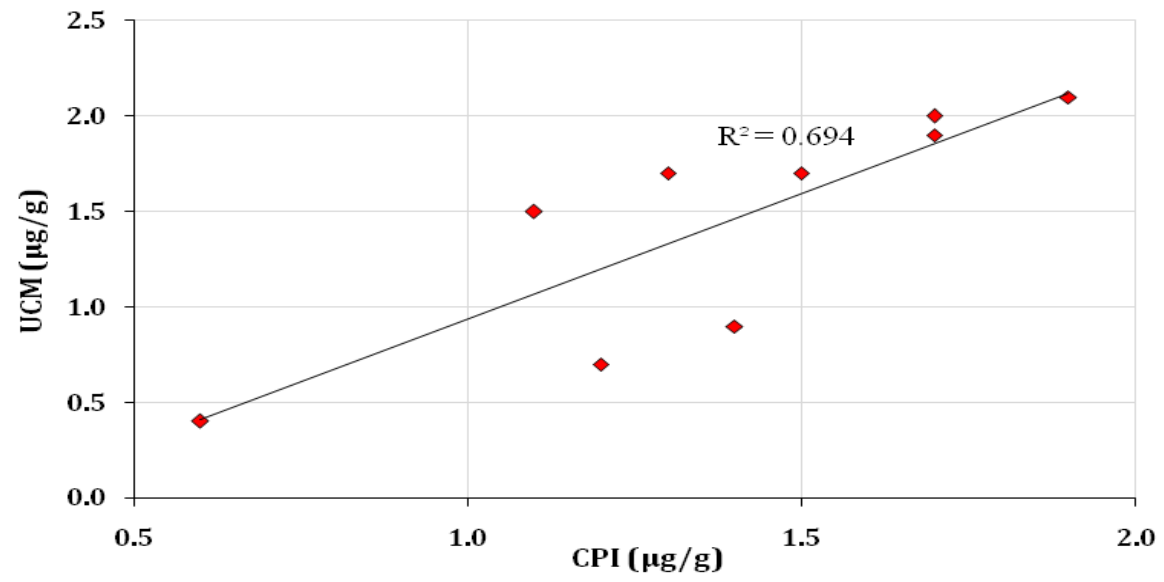

Figure 3. Relationship between UCM and CPI.

The results of $\sum$ AHs in surface sediment samples from Aden coasts are given in Table 1 and shown in Figure 1. Concentrations of $\sum$ AHs ranged between $6.25 \mu \mathrm{g} / \mathrm{g}$ (station 5) to $41.05 \mu \mathrm{g} / \mathrm{g}$ (station 7), with an average of 


\section{PETROLEUM HYDROCARBON RESIDUES}

$16.49 \pm 11.67 \mu \mathrm{g} / \mathrm{g}$ (Figure 4). Station 5 is taken as the background level for this study. Little or no pollution is considered to exist when $\sum \mathrm{AH}$ concentration is $<10 \mu \mathrm{g} / \mathrm{g}$ and sediments are considered polluted when the concentration is $>100 \mu \mathrm{g} / \mathrm{g}$ [40]. Hence, as all stations exhibited values $<41.05 \mu \mathrm{g} / \mathrm{g}$, this clearly indicates that surface sediments in Aden coasts are low polluted.

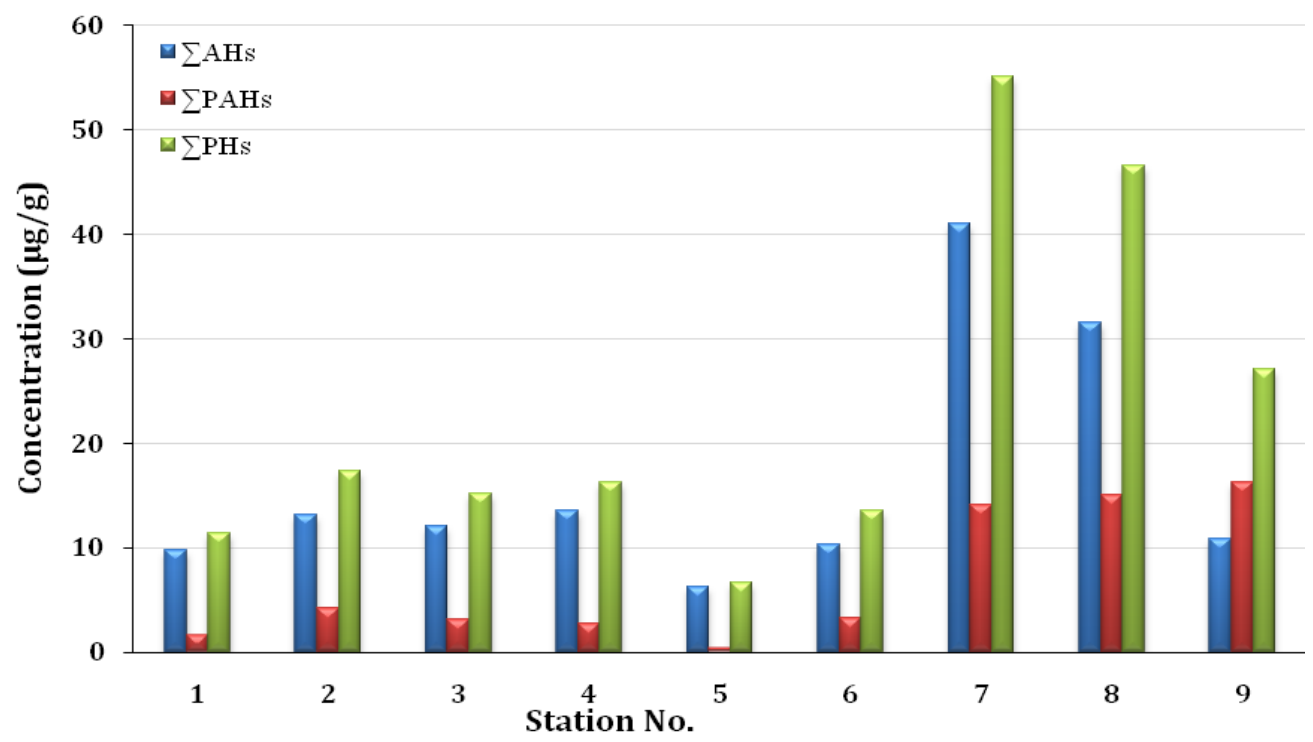

Figure 4. Concentration of $\sum$ AHs, $\sum$ PAHs and $\sum$ PHs in surface sediment samples from nine stations along Aden coasts.

Concentrations of PAHs in the sediment samples from some Aden city coasts are summarized in Table 2. The PAHs consist of two groups: low molecular weight PAHs (naphthalene, biphenyl, phenanthrene and anthracene) and high molecular weight (fluoranthene, pyrene, chrysene, benzopyrene and perylene).

Concentrations of $\sum$ PAHs in the sediments ranged between $0.37 \mu \mathrm{g} / \mathrm{g}$ (station 5) and $16.30 \mu \mathrm{g} / \mathrm{g}$ (station 9), with an average of $7.38 \mu \mathrm{g} / \mathrm{g}$ (Table 2, Figure 4). PAH concentrations can be described as low pollution $(<100 \mu \mathrm{g} / \mathrm{g})$ or chronically polluted $(>1000 \mu \mathrm{g} / \mathrm{g}$ ) [41]. Hence, Aden's coastal sediments are low polluted with PAHs (values $\leq 16.30$ $\mu \mathrm{g} / \mathrm{g})$. The possible sources of PAHs at station 9 were oil leakage, and the refinery, port area and shipping operations. Similar conclusions were reached by $[22,42,43]$.

The main sources of PAHs in aquatic systems are pyrolytic or petrogenic sources $[44,45]$. Pyrolytic PAHs which are derived from combustion contain four or more aromatic rings, while petrogenic PAHs derived from petroleum contain less than four aromatic rings $[41,46]$.

Table 2. Concentration of PAHs in sediment samples from some Aden city coasts of Yemen (in $\mu \mathrm{g} / \mathrm{g}$ dry weight).

\begin{tabular}{|c|c|c|c|c|c|c|c|c|c|}
\hline & \multicolumn{9}{|c|}{ Station No. } \\
\hline Compounds & 1 & 2 & 3 & 4 & 5 & 6 & 7 & 8 & 9 \\
\hline Naphthalene & 0.03 & 0.04 & 0.03 & 0.04 & 0.02 & 0.07 & 1.50 & 1.70 & 1.90 \\
\hline Biphenyl & 0.01 & 0.03 & 0.03 & 0.05 & 0.01 & 0.03 & 1.20 & 1.10 & 1.20 \\
\hline Phenanthrene (Phe) & 0.08 & 1.00 & 0.09 & 0.09 & 0.06 & 0.10 & 1.10 & 1.20 & 1.30 \\
\hline Anthracene (Ant) & 0.04 & 0.06 & 0.05 & 0.03 & 0.04 & 0.08 & 1.40 & 1.50 & 1.60 \\
\hline Fluoranthene (Flu) & 0.03 & 0.06 & 0.05 & 0.04 & 0.03 & 0.07 & 1.20 & 1.30 & 1.40 \\
\hline Pyrene (Py) & 0.05 & 0.09 & 0.08 & 0.07 & 0.07 & 0.08 & 1.30 & 1.50 & 1.70 \\
\hline Chrysene & 0.30 & 0.07 & 0.07 & 0.08 & 0.05 & 0.06 & 1.90 & 2.00 & 2.00 \\
\hline Benzopyrene & 1.00 & 1.50 & 1.30 & 1.20 & 0.09 & 1.30 & 2.50 & 2.70 & 2.90 \\
\hline Perylene & 0.08 & 1.30 & 1.40 & 1.10 & ND & 1.40 & 2.00 & 2.10 & 2.30 \\
\hline$\sum$ PAHs & 1.62 & 4.15 & 3.10 & 2.70 & 0.37 & 3.19 & 14.10 & 15.10 & 16.30 \\
\hline Flu/(Flu+Pyr) & 0.38 & 0.40 & 0.38 & 0.36 & 0.30 & 0.47 & 0.48 & 0.46 & 0.45 \\
\hline Ant/(Ant+Phe) & 0.33 & 0.06 & 0.36 & 0.25 & 0.40 & 0.44 & 0.56 & 0.56 & 0.55 \\
\hline Flu/Pyr & 0.60 & 0.67 & 0.63 & 0.57 & 0.43 & 0.88 & 0.92 & 0.87 & 0.82 \\
\hline
\end{tabular}

In this study, to identify the possible sources of PAHs, PAH isomers of masses Flu/Pyr and Flu/(Flu+Pyr) were used to differentiate between pyrolytic and petrogenic sources. All stations exhibited values of the Flu/Pyr ratio between 0.43 and 0.90 . For Flu/(Flu+Pyr) ratio, all station's values ranged between 0.30 and 0.48 . The Flu/Pyr and $\mathrm{Flu} /($ Flu+Pyr) ratios are useful indicators for evaluating the attribution of PAH pollution in sediments [47]. If the Flu/Pyr ratio is higher than 1, PAHs will have a pyrolytic source, but when the ratio is lower than one, their source is 
from petroleum. Moreover, if Flu/(Flu+Pyr) $>0.50$, a pyrolytic source from the combustion of a biomass or coal is indicated [46]. As shown in Figure 5, the ratios of Flu/Pyr in all studied stations were $<1$. This implies that the source of PAHs in surface sediments could mainly pollution by petrogenic inputs.

Concentrations of total PHs ( $\sum$ PHs) as the sum of $\sum$ AHs and $\sum$ PAHs in the sediment samples are given in Table 3, Figure 4. These ranged from $6.62 \mu \mathrm{g} / \mathrm{g}$ (station 5) to $55.15 \mu \mathrm{g} / \mathrm{g}$ (station 7), with an average of $23.22 \mu \mathrm{g} / \mathrm{g}$. A $\sum \mathrm{PHs}$ concentration $<10 \mu \mathrm{g} / \mathrm{g}$ indicates unpolluted sediments, whereas a concentration $>500 \mu \mathrm{g} / \mathrm{g}$ shows that sediments are highly polluted $[5,37]$. Hence Aden's coastal sediments are low polluted with PHs and station 5 is unpolluted.

Based on the results of the grain size distribution, surface sediments in all the sampling stations were characterized as sandy (Table 3).

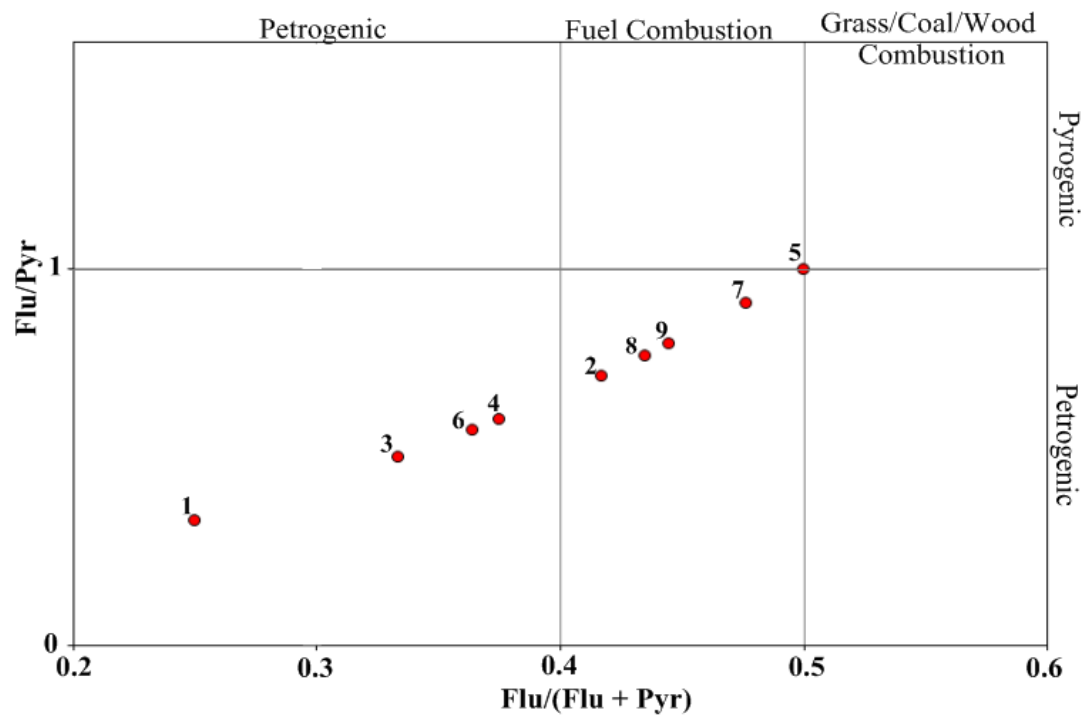

Figure 5. Plots of the isomeric ratios a) Ant/(Ant+Phe) versus Flu/(Flu+Py) and b) Flu/(Flu+Pyr) versus Flu/Py.
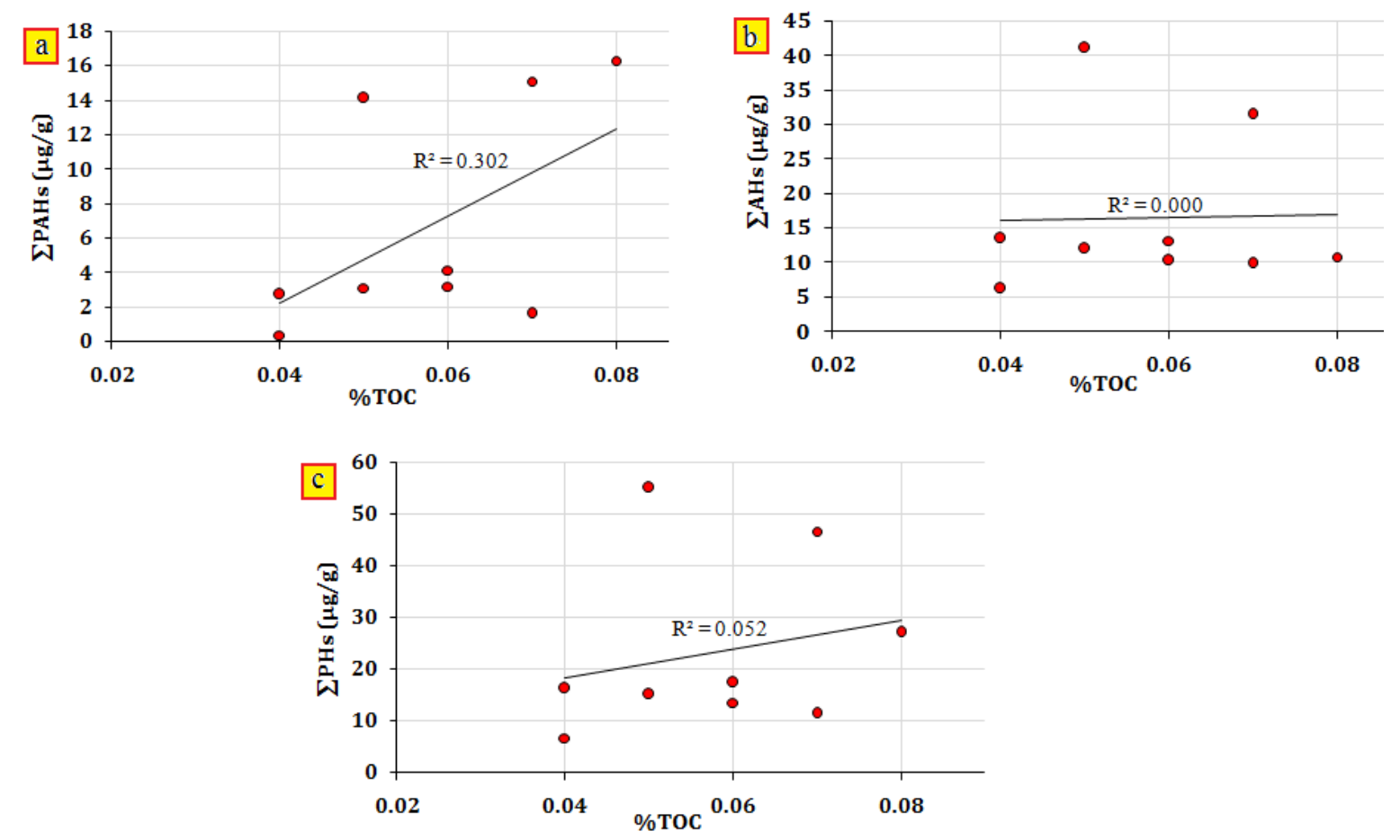

Figure 6. Relationships between a) \%TOC and $\sum \mathrm{PAHs}$, b) \% $\mathrm{TOC}$ and $\sum \mathrm{AHs}$ c) $\% \mathrm{TOC}$ and $\sum \mathrm{PHs}$. 


\section{PETROLEUM HYDROCARBON RESIDUES}

Table 3. $\mathrm{pH}, \% \mathrm{TOC}$ and $\sum \mathrm{PHs}$ concentration in surface sediment samples from some Aden city coasts with their sediments type.

\begin{tabular}{c|c|c|c|c}
\hline Station No. & $\mathbf{p H}$ & $\boldsymbol{\%}$ TOC & $\sum$ PHs $(\mu \mathrm{g} / \mathrm{g})$ & Sediment type \\
\hline $\mathbf{1}$ & 8.01 & 0.07 & 11.39 & Medium sand \\
\hline $\mathbf{2}$ & 8.01 & 0.06 & 17.33 & Very fine sand \\
\hline $\mathbf{3}$ & 8.00 & 0.05 & 15.12 & Very fine sand \\
\hline $\mathbf{4}$ & 8.02 & 0.04 & 16.22 & Medium sand \\
\hline $\mathbf{5}$ & 8.03 & 0.04 & 06.62 & Coarse sand \\
\hline $\mathbf{6}$ & 7.80 & 0.06 & 13.50 & Fine sand \\
\hline $\mathbf{7}$ & 8.02 & 0.05 & 55.15 & Fine sand \\
\hline $\mathbf{8}$ & 7.93 & 0.07 & 46.60 & Fine sand \\
\hline $\mathbf{9}$ & 7.92 & 0.08 & 27.09 & Very fine sand \\
\hline Average & 7.97 & 0.06 & 23.22 & - \\
\hline STDEV & 0.07 & 0.01 & 16.73 & - \\
\hline
\end{tabular}

The results of \%TOC and fine fraction in surface sediment samples of Aden coasts is presented in (Table 3). The \% TOC content in Aden coast sediments ranged from $0.04 \%$ (stations 4 and 5) to $0.08 \%$ (station 9), with an average value of $0.06 \%$ (Table 3). This would be considered low in organic matter $(<0.50 \%)$ [48]. Low values of $\%$ TOC may be influenced by the $\mathrm{pH}$. High $\mathrm{pH}$ values may contribute to low organic matter accumulation, while increasing anoxic degradation rates [49]. Tongo et al. [49] observed a higher organic matter content in acidic sediment samples. In this study, the average $\mathrm{pH}$ was 7.97 (ranging from 7.80 to 8.03), which indicates an alkaline sediment. No significant correlation between \% TOC and grain size fractions was observed.

In this study, the regression analysis was used to determine the relationship between the concentration of residual hydrocarbons ( $\Sigma$ PAHs, $\Sigma$ AHs and $\Sigma$ PHs) and \%TOC in sediments (Figure 6). The linear regressions between $\Sigma$ PAHs and \% TOC show weak positive correlation $\left(\mathrm{R}^{2}=0.30\right)$ (Figure 6a). Mostafa et al. [14,50] demonstrated similar results of weak positive correlation of sediments from coastal areas. These studies and the present results, suggest that the distribution and concentration of $\sum$ PAHs in sediments are affected and related by direct input to marine environment, rather than by the type of the sediment found locally. No significant correlation between \%TOC and $\Sigma$ AHs or $\Sigma$ PHs were observed (Figure $6 \mathrm{~b}$ and $\mathrm{c}$ ).

\section{Conclusion}

Surficial sediment samples from Aden city coasts, Yemen were analysed for AHs and PAHs to determine the distribution, composition and source of organic matter in this coastal environment. $\sum$ AHs concentrations ranged from $6.25 \mu \mathrm{g} / \mathrm{g}$ in station 5 to $41.04 \mu \mathrm{g} / \mathrm{g}$ in station 7 with an average value of $16.49 \mu \mathrm{g} / \mathrm{g}$. $\sum$ PAHs concentrations ranged between $0.37 \mu \mathrm{g} / \mathrm{g}$ in station 5 and $16.30 \mu \mathrm{g} / \mathrm{g}$ in station 9 with an average value of $7.38 \mu \mathrm{g} / \mathrm{g}$. The surface sediments in all the sampling stations were characterized as sandy. The concentration of $\%$ TOC is not related to grain size, $\sum$ AHs or $\sum$ PAHs. The concentration of $\sum$ AHs, $\sum$ PAHs and $\sum$ PHs is not related to grain size or \% TOC. The observed Sq, UCM, $\mathrm{CPI}, \mathrm{Pr} / \mathrm{Pa}$ ratio, Flu/Pyr ratio and Flu/(Flu+Pyr) ratio indicate pollution by PHs. The study shows that the levels of hydrocarbon in sediments of the Aden coasts are low and within the allowed limits. The pattern of the distribution of PAHs in the sediments appears to be governed mainly by their proximity to potential oil pollution sources.

This study provides useful data for assessing the effect of marine petroleum pollution control measures from the perspective of human health.

It is recommended that a continuous monitoring programme for the Aden city coasts, Yemen and Red Sea and Gulf of Aden region should be formulated and conducted, to ensure that the concentration of PHs is within the base line level established in the present study. 


\section{Acknowledgement}

The authors wish to express their sincere gratitude and appreciation to Dr. Hisham M. Nagi, Earth and Environmental Science Department, Faculty of Science, Sana'a University, and the anonymous reviewers for valuable comments and suggestions to improve the manuscript.

\section{References}

1. Li, F., Lin, J.Q., Liang, Y.Y., Gan, H.Y., Zeng, X.Y., Duan, Z.P., Liang, K., Liu, X., Huo, Z.H., and Wu, C.H. Coastal surface sediment quality assessment in Leizhou Peninsula (South China Sea) based on SEM-AVS analysis, Marine Pollution Bulletin, 2014, 84, 424-436.

2. Kapsimalis, V., Panagiotopoulos, I.P., Talagani, P., Hatzianestis, I., Kaberi, H., Rousakis, G., Kanellopoulos, T.D., and Hatiris, G.A. Organic contamination of surface sediments in the metropolitan coastal zone of Athens, Greece: sources, degree, and ecological risk, Marine Pollution Bulletin, 2014, 80, 312-324.

3. Wu, Y., Zhang, J., Mi, T., and Li, B. Occurrence of n-alkanes and polycyclic aromatic hydrocarbons in the core sediments of the Yellow Sea, Marine Chemistry, 2001, 76, 1-15.

4. Gao, X., and Chen, S. Petroleum pollution in surface sediments of Daya Bay, South China, revealed by chemical fingerprinting of aliphatic and alicyclic hydrocarbons, Estuarine, Coastal and Shelf Science, 2008, 80, 95-102.

5. Volkman, J.K., Holdsworth, D.G., Neill, G.P., and Bavor, H.J. Identification of natural, anthropogenic and petroleum hydrocarbons in aquatic sediments, The Science of Total Environment, 1992, 112, 203-219.

6. NRC, Oil in the Sea: Inputs, Fates, and Effects, National Academy Press, Washington DC. 2003, p. 265.

7. Asia, L., Mazouz, S., Guiliano, M., Doumeq, P., and Mille, G. Occurrence and distribution of hydrocarbons in surface sediments form Marseille Bay (France), Marine Pollution Bulletin, 2009, 58, 424-455.

8. Maioli, O.L.G., Rodrigues, K.C., Knoppers, B.A., and Azevedo, D.A. Distribution and sources of polyciclic aromatic hydrocarbon in surface sediments from two Brazilian Estuarine Systems, Journal of Brazilian Chemical Society, 2010, 21(8), 1543-1551.

9. Macias-Zamora, J.V. Distribution of hydrocarbon in recent marine sediments off the coast of Baja California. Environmental Pollution, 1996, 92(1), 45-53.

10. WHO, Guidelines for Indoor Air, Selected Pollutants; Polycyclic Aromatic Hydrocarbons, 2010, p. 289.

11. Ahmed, M.M., Doumenq, P., Awaleh, M.O., Syaktib, A.D., Asia, L., and Chiron, S. Levels and sources of heavy metals and PAHs in sediment of Djibouti-city (Republic of Djibouti), Marine Pollution Bulletin, 2017, 120, 340346.

12. Nascimento, R.A., Almeida, M., Escobar, N.C.F., Ferreira, S.L.C., Mortatti, J., and Queiroz, A.F.S. Sources and distribution of polycyclic aromatic hydrocarbons (PAHs) and organic matter in surface sediments of an estuary under petroleum activity influence, Todosos Santos Bay, Brazil, Marine Pollution Bulletin, 2017, 119, 223-230.

13. Ramzi, A., Habeeb, R.K., Gireeshkumar, T.R., Balachandran, K.K., and Chandramohanakumar, N. Dynamics of polycyclic aromatic hydrocarbons (PAHs) in surface sediments of cochin estuary, India. Marine Pollution Bulletin, 2017, 114, 1081-1087.

14. Mostafa, A.R., Barakat, A.O., Qian, Y., and Wade, T.L. Composition, distribution and sources of polycyclic aromatic hydrocarbons in sediments of the western harbour of Alexandria, Egypt. J. Soils Sediments, 2003, 3, 173179.

15. MFW, Guide to fishes, Ministry of Fish Wealth, Marine Science and Resources center, Yemen, 2001.

16. Heba, H.M.A., Maheub, A.R.S., and Al- Shawafi, N. Oil pollution in Gulf of Aden/ Arabian Sea Coasts of Yemen, Bulletin of National Institute Oceanography and fisheries, 2000, 26, 271-282.

17. Wenink, C.R., and Nelson-Smith, A. Coastal oil pollution study for the Gulf of Suez and Red Sea coast of the Republic of Egypt, 1979, IMCO, London.

18. Dicks, B. Pollution. In: Red Sea (Key Environments). Edited by Edwards. A.J. and S.M. Head. Pergamon Press, Oxford, 1987, p. 44.

19. DouAbul, A.A.Z., and Heba, H.M.A. Investigations following a fish kill in Bab el-Mandeb, Red Sea during November 1994. Report submitted to Environmental Protection Council (EPC) (Dutch Support Project to Technical Secretariat EPC, Yemen) 1995, p. 105.

20. DouAbul, A.A.Z., and Al-Shwafi, N.A. Petroleum hydrocarbons in the Red Sea coast of Yemen. Paper accepted in the International Conference on the Biology of Coastal Environment (ICBCE 97), 1997, Bahrain, 4-7 April 1997.

21. Al-Alimi, A.A. Assessment of sources and levels of persistent organic pollutant (POPS) and trace metals in the coastal environment of Hadhramout Governorate, Yemen. Ph.D. Thesis, Faculty of Science, Alexandria, Egypt. 2008, p. 243.

22. Grimalt, J., Albaiges, J. Al-Saad, H.T., and DouAbul, A.A.Z. n-Alkane distribution in surface sediments from the Arabian Gulf ; Naturwissenschaften, 1985, 72, 35-38.

23. Al-Shwafi, N.A. Hydrographical Studies on the Gulf of Aden around Aden City, Yemen, Nature Environment and Pollution Technology, An International Quarterly Scientific Journal, 2012, 11 (3), 519-522.

24. UNEP/IOC/IAEA, Determination of petroleum hydrocarbons in sediments. In: Reference Methods for Marine Pollution Studies, 1992, Nairobi: UNEP. p. 75. 


\section{PETROLEUM HYDROCARBON RESIDUES}

25. Botsou, F., Hatzianestis, I., Polycyclic aromatic hydrocarbons (PAHs) in marine sediments of the Hellenic coastal zone, eastern Mediterranean: levels,sources and toxicological significance, Journal Soils Sediments, 2012, 12, 265277.

26. Farrington, J.W., Frew, N. M., Gachwend, P.M., and Tripp, B.W. Hydrocarbons in cores of northwestern Atlantic Coastal and continental margin sediments, Estuarine, Coastal and Shelf Science, 1977, 1, 71-79.

27. Folk, R.I. Petrology of Sedimentary Rocks, Hemphill Publishing Co. 1974, Austin, Texas.

28. Riley, J.P. and Chester, R. Introduction to marine chemistry; Academic Press, 1981, London, pp. 465.

29. Burns, K.A., Villeneuve, J.P., Anderlini, V.C., and Fowler, S.W. Survey of tar, hydrocarbonand metal pollution in the coastal waters of Oman, Marine Pollution Bulletin, 1982, 13, 204-207.

30. Steinhauer, S.S., and Boehm, P.D. The composition and distribution of saturated and aromatic hydrocarbons in nearshore sediments, river sediments and coastal peat of the Alaskan Beaufort Sea: implications for detecting anthropogenic hydrocarbon inputs. Marine Environmental Resources, 1992, 33, 223-253.

31.Zaghden, H., Kallel, M., Elleuch, B., Oudot, J., and Saliot, A. Sources and distribution of aliphatic and polyaromatic hydrocarbons in sediments of Sfax, Tunisia, Mediterranean Sea. Marine Chemistry, 2007, 105, 70-89. http://dx.doi.org/10.1016/j.marchem.2006.12.016.

32. Commendatore, M.G., Nievas, M.L., Amin, O., and Esteves, J.L. Sources and distribution of aliphatic and polyaromatic hydrocarbons in coastal sediments from the Ushuaia Bay (Tierra del Fuego, Patagonia, Argentina). Marine Environmental Resources, 2012, 74, 20-31.

33. Matsumoto, G., and Hanya, T. Comparative study on organic constituent in polluted and unpolluted inland aquatic environment. Features of hydrocarbons for polluted and unpolluted waters, Water Resources, 1981, 15, $217-224$.

34. Frysinger, G.S., Gaines, R.B., Xu, L., and Reddy, C.M. Resolving the unresolved complex mixture in petroleumcontaminated sediments, Environmental Science Technology, 2003, 37, 1653-1662.

35. Commendatore, M.G., and Esteves, J.L. Natural and anthropogenic hydrocarbons in sediments from the Chubut River (Patagonia, Argentina), Marine Pollution Bulletin, 2004, 48, 910-918.

36. Jeng, W.L. Higher plant n-alkane average chain length as an indicator of petrogenic hydrocarbon pollution in marine sediments, Marine Chemistry, 2006, 102, 242-251.

37. Maioli, O.L.G., Rodrigues, K.C., Knoppers, B.A., and Azevedo, D.A. Pollution source evaluation using petroleum and aliphatic hydrocarbons in surface sediments from two Brazilian estuarine systems. Organic Geochemistry, 2010, 41, 970-996.

38. Kucuksezgin, F., Pazi, I., and Gonul, L.T. Marine organic pollutants of the Eastern Aegean: aliphatic and polycyclic aromatic hydrocarbons in Candarli Gulf surficial sediments, Marine Pollution Bulletin, 2012, 64, 25692575 .

39. Vaezzadeh, V., Zakaria, M.P., Shau-Hwai, A.T., Ibrahim, Z.Z., Mustafa, S., Abootalebi- Jahromi, F., Masood, N., Magam, S.M., and Alkhadher, S.A. Forensic Investigation of Aliphatic Hydrocarbons in the Sediments From Selected Mangrove Ecosystems in the West Coast of Peninsular Malaysia, Marine Pollution Bulletin, 2015.

40. Wang, M., Wang, C., Hu, X., Zhang, H., He, S., and Lv, S. Distributions and sources of petroleum, aliphatic hydrocarbons and polycyclic aromatic hydrocarbons (PAHs) in surface sediments from Bohai Bay and its adjacent river, China, Marine Pollution Bulletin, 2015, 90, 88-94.

41. Readman, J.W., Fillmann, G., Tolosa, I., Bartocci, J., Villeneuve, J.P., Cattini, C., and Mee, L.D. Petroleum and PAH contamination of the Black Sea. Marine Pollution Bulletin, 2002, 44, 48-62.

42. Baumard, P., Budzinski, H., and Garrigues, P. Polycyclic aromatic hydrocarbons in sediments and mussels of the western Mediterranean Sea, Environmental Toxicology Chemistry, 1998, 17, 765-776.

43. DouAbul, A.A.Z., Al-Saad, H.T., and Darmoian, S.A. Distribution of petroleum residues in surficial sediments from Shatt Al-Arab river and the north-west region of the Arabian Gulf, Marine Pollution Bulletin, 1984, 15, 198200.

44. Al-Shwafi, N.A. Distribution of Aliphatic and Polynuclear Aromatic Hydrocarbons (PAHs) in Surficial Sediments from the Red Sea of Yemen. Journal of King Abdulaziz University: Marine Science, 2003, 14, 89-97.

45.Zakaria, M.P., Takada, H., Tsutsumi, S., Ohno, K., Yamada, J., Kouno, E., and Kumata, H. Distribution of polycyclic aromatic hydrocarbons (PAHs) in rivers and estuaries in Malaysia: a widespread input of petrogenic PAHs, Environmental Science Technology, 2002, 36, 1907-1918.

46. Stout, S.A., Uhler, A.D., and Emsbo-Mattingly, S.D. Comparative evaluation of background anthropogenic hydrocarbons in surficial sediments from nine urban waterway, Environmental Science Technology, 2004, 38, 2987-2994.

47. Yunker, M.B., Macdonald, R.W., Vingarzan, R., Mitchell, R.H., Goyette, D., and Sylvestre, S. PAHs in the Fraser River basin: a critical appraisal of PAH ratios as indicators of PAH source and composition, Organic Geochemistry, 2002, 33, 489-515.

48. Li, G., Xia, X., Yang, Z., Wang, R., and Voulvoulis, N. Distribution and sources of polycyclic aromatic hydrocarbons in the middle and lower reaches of the Yellow River, China, Environmental Pollution, 2006, 144, 985-993.

49. Gomes, A.O., and Azevedo, D.A. Aliphatic and aromatic hydrocarbons in tropical recent sediments of Campos dos Goytacazes, RJ, Brazil, Journal of Brazilian Chemistry Society, 2003, 14, 358-368. 
50. Tongo, I., Ezemonye, L., and Akpeh, K. Levels, distribution and characterization of polycyclic aromatic hydrocarbons (PAHs) in Oviariver, southern Nigeria, Journal of Environmental Chemistry Engineering, 2017, 5, 504-512.

51. Mostafa, A.R., Wade, T.L., Sweet, S.T., Al-Alimi, A.A. and Barakat, A.O. Distribution and characteristics of polycyclic aromatic hydrocarbons (PAHs) in sediments of Hadhramout coastal area, Gulf of Aden, Yemen, Journal of Marine Systems, 2009, 78, 1-8.

Received 24 April 2018

Accepted 8 December 2018 